\title{
Autres publications de l'ASPC
}

Les chercheurs de l'Agence de la santé publique du Canada contribuent également à des travaux publiés dans d'autres revues. Voici quelques articles publiés en 2017.

Foster WG, Evans JA, Little J, [...] León JA, Luo W. Human exposure to environmental contaminants and congenital anomalies: a critical review. Crit Rev Toxicol. 2017;47(1):59-84. doi: 10.1080/10408444.2016.1211090.

Liu S, Metcalfe A, León JA, Sauve R, Kramer MS, Joseph KS. Evaluation of the INTERGROWTH-21st project newborn standard for use in Canada. PLOS ONE. 2017;12(3). doi: 10.1371/journal.pone.0172910.

Thombs BD, Garcia AJ, Reid D, Pottie K, Parkin P, Morissette K, et al. Recommendations on behavioural interventions for the prevention and treatment of cigarette smoking among school-aged children and youth. CMAJ. 2017;189(8):E310-E316. doi: 10.1503/cmaj.161242.

Trecker MA, Dillon J-R, Lloyd K, Hennink M, Jolly A, Waldner C. Can social network analysis help address the high rates of bacterial sexually transmitted infections in Saskatchewan? Sex Transm Dis. 2017. doi: 10.1097/OLQ.0000000000000599.

Wilson SE, Quach S, MacDonald SE, [...] Desai S. Immunization information systems in Canada: attributes, functionality, strengths and challenges. A Canadian immunization research network study. Can J Public Health. 2017;107(6):e575-e582. doi: 10.17269/cjph.107.5679. 